Jurnal IImiah Potensia, 2019, Vol. 4 (2), 87-94

https://ejournal.unib.ac.id/index.php/potensia

e-issn: 2621-2382 p-issn: 2527-9270

\title{
Pelaksanaan Kegiatan Ekstrakurikuler Tari Tradisional di Taman Kanak-Kanak Sani Ashila Padang
}

\author{
Indra Yeni ${ }^{2}$ \\ Yaswinda ${ }^{3}$
}

Winda Trimelia Utami ${ }^{1}$

windatrimeliautami@gmail.com

1, 2, 3 Program Studi Pendidikan Guru Pendidikan Anak Usia Dini, Universitas Negeri Padang

Received: November $30^{\text {th }} 2018$

Accepted: July $4^{\text {th }} 2019$

Published: July $22^{\text {nd }} 2019$

\begin{abstract}
Kegiatan ekstrakurikuler merupakan penunjang dari kegiatan akademik di lembaga PAUD. Hal ini perlu diterapkan diseluruh lembaga ini. Oleh karena itu penelitian ini bertujuan untuk mengetahui pelaksanaan kegiatan ekstrakurikuler tari tradisional di Taman Kanakkanak Sani Ashila Padang dalam rangka mengetahui penerapannya. Metode penelitian yang digunakan adalah deskriptif dengan pendekatan kualitatif. Hasil penelitian menunjukkan bahwa kegiatan ekstrakurikuler tari tradisional di TK Sani Ashila Padang belum sesuai dengan tahap-tahap pengenalan tari kepada anak. Namun dengan latihan yang rutin dapat mengantarkan TK Sani Ashila Menjuarai beberapa Lomba Tari. Melalui kegiatan ini juga sebagai wahana untuk memperkenalkan kebudayaan pada anak dan juga untuk membantu perkembangan motoriknya. Kendala yang sering terjadi adalah suasana hati anak yang berubah drastis, sehingga guru harus membujuk anak agar bersemangat kembali. Tempat latihan yang digunakan berukuran $4 \times 4 \mathrm{~m}$ tidak sebanding dengan jumlah anak yang mengikuti kegiatan. Dari penelitian ini disimpulkan bahwa pelaksanaan kegiatan ekstrakurikuler tari tradisional di Taman Kanak-kanak Sani Ashila Padang belum berjalan dengan baik.
\end{abstract}

Keywords: Ekstrakurikuler; Tari Tradisional; Pelaksanaan Kegiatan; Metode Deskriptif

How to cite this article:

Utami, W., Yeni, I., \& Yaswinda, Y. (2019). Pelaksanaan Kegiatan Ekstrakurikuler Tari Tradisional di Taman Kanak-kanak Sani Ashila Padang. Jurnal IImiah POTENSIA, 4(2), 87-94. doi:https://doi.org/10.33369/jip.4.2.87-94

\section{PENDAHULUAN}

Pendidikan anak usia dini (PAUD) dalam Peraturan Menteri Pendidikan dan Kebudayaan Republlik Indonesia Nomor 146 Tahun 2014 adalah suatu upaya pembinaan yang ditujukan kepada anak sejak lahir sampai usia 6 tahun yang dilakukan melalui rangsangan pendidikan, untuk membantu perkembangan jasmani dan rohani agar memiliki kesiapan memasuki pendidikan lebih lanjut. Terdiri atas Taman Penitipan Anak (TPA), Satuan
PAUD Sejenis, Kelompok Bermain (KB), dan Taman Kanak-kanak (TK) atau Raudhatul Athfal (RA).

Taman Kanak-kanak (TK) adalah jenjang pendidikan anak usia dini Usia 4-6 tahun dan merupakan jenjang pendidikan formal yang memegang peran penting dalam proses mengembangkan kepribadian dan aspek perkembanga anak serta mempersiapkan anak menuju pendidikan selanjutnya. 
Sebagai lembaga yang memiliki peran yang sangat penting dalam masa Golden Age, masa-masa yang sangat berharga bagi anak yang merupakan pijakan kepada perkembangan selanjutnya, diperlukan penunjang yang dapat mendukung pengembangan dan pembinaan potensi anak baik secara akademik maupun non akademik. Karena setiap anak itu unik memiliki karakter dan kecenderungan masing-masing. Tidak semua anak berprestasi dan menonjol dalam bidang akademik, sebagian anak memiliki bakat dibidang non akademik.

Kegiatan non akademik di sekolah biasa disebut dengan kegiatan ekstrakurikuler atau kegiatan di luar materi pelajaran wajib. Kegiatan ini ada pada setiap jenjang pendidikan dari Taman Kanak-kanak hingga tingkat Universitas. Menurut Hadiyanto (2014: 162-163), "kegiatan ekstrakurikuler merupakan kegiatan yang di lakukan diluar jam pelajaran biasa, pada waktu libur, di dalam maupun di luar sekolah, secara rutin atau hanya pada waktu tertentu saja".

Kegiatan ekstrakurikuler yang bisa dikembangkan di sekolah sangat beragam, seperti ekstrakurikuler dibidang olahraga, seni, dan lain-lain. Salah satu kegiatan ekstrakurikuler dibidang seni adalah seni tari tradisional. Menurut Astuti (2016: 51) tari tradisional adalah tari yang berasal dari masyarakat yang telah diwariskan secara turun temurun, keberadaanya telah mengalami suatu perjalanan yang cukup lama dan selalu berpola pada kaidah-kaidah (tradisi) yang sudah ada.

Menurut Mulyani (2016: 61-64) tujuan tari tradisional adalah diharapkan untuk melestraikan kebudayaan leluhur sebagai pelengkap kebutuhan dalam kehidupan sosial, dan bukan semata-mata untk mendapatkan hiburan saja. Manfaat tari Tradisional diantaranya dapat mengenalkan budaya, dan menanamkan nilai-nilai, norma-norma, peraturan- peraturan dalam kebudayaan. Selain itu juga dapat mengembagkan berbagai aspek meliputi pengembangan aspek pengetahuan, aspek keterampilan, aspek afektif, dan aspek kreatif. (Kusumawati, 2018).

Tari bagi anak usia dini bukanlah sekedar gerak tari tanpa makna dan tujuan, Menurut Mulyani (2017: 68) Tari anak usia dini adalah "suatu proses dalam mendidik anak agar mampu mengontrol dan menginterprestasikan gerak tubuh, memanipulasi benda-benda dan menumbuhkan harmoni antara tubuh dan pikiran". Sejalan dengan Yetti dalam Mulyani (2017: 18) tari anak usia dini adalah kegiatan yang menekankan pada gerak motorik halus maupun motorik kasar yang dapat mengembangkan kecerdasan anak.

Tari juga memliki fungsi bagi anak yaitu menurut Rahmida dalam Astuti (2016: 71) Tari anak usia dini adalah sebagai: 1) media pendidikan, 2) media ekspresi, 3) Media bermain, 4) media komunikasi, 5) media pengembangan bakat. Sedangkan menurut Astuti (2016: 80-87) fungsi tari di sekolah adalah untuk perkembangan anak diantaranya: 1) meningkatkan pertumbuhan fisik. mental dan estetik, 2) memberikan sumbanganke arah sadar diri, 3) membina imajinasi kreatif, 4) memberi untuk pemecahan masalah, 5) memurnikan cara berpikir, berbuat dan menilai, 6) perkembangan kepribadian, 7) membina perkembangan estetik, 8) menyempurnakan kehidupan.

Tari anak usia dini tidaklah sama dengan tari untuk orang dewasa karena tari anak usia dini adalah tari yang ditujukan untuk mengembangkan seluruh aspek perkembangan anak dan juga harus dekat dengan anak. Menurut Astuti (2016: 162) karakteristik tari anak usia dini adalah disesuaikan dengan kemampuan dasar untuk mengembangkan seluruh potensi dasar anak yang lebih ditekankan pada 


\section{Jurnal Ilmiah Potensia, 2019, Vol. 4 (2), 87-94}

https://ejournal.unib.ac.id/index.php/potensia e-issn: 2621-2382 p-issn: 2527-9270

proses, dengan konsep melalui kegiatan bermain, sehingga menarik bagi anak dan anak dapat mengekspresikan dirinya secara utuh.

Manfaat Tari anak Usia dini Menurut Haryati (2014) manfaat tari bagi anak usia dini adalah memberikan manfaat dalam berbagai aspek kehidupan diantaranya: 1) aspek kesehatan dengan tercapainya kelenturan gerak badan, meningkatkan kemampuan motorik kasar, dan kesehatan badan, 2) aspek kecerdasan dengan meningkatnya kecerdasan anak, melatih anak untuk berfikir kritis, berfikir fleksibel, cepat, dan tepat, 3) Aspek psikologis dengan mengembangkan kepercayaan diri, dan semangat positif dan kreativitas, 4) aspek sosial dengan meningkatkan sikap kerja sama, kekompakan dan penghargaan, 5) Aspek estetika dengan menumbuhkan rasa keindahan, mengasah kehalusan budi dan kepekaan jiwa.

Berdasarkan fenomena di atas peneliti tertarik untuk meneliti pelaksanaan pembelajaran ekstrakurikuler tari tradisional di taman kanak-kanak. Ketertarikan tersebut berdasarkan asumsi peneliti bahwa pembelajaran tari tradisional sangat penting dilakukan di taman kanak-kanak. Dalam hal ini juga dalam pelaksanaannya membutuhkan proses dan tahap yang kompleks. Peneliti memilih TK Sani Ashila karena berdasarkan observasi awal yang peneliti lakukan di TK Sani Ashila Padang. Peneliti melihat adanya program extrakurikuler tari tradisional yang mempunyai ke unggulan prestasi-prestasi yang di raihnya. Selain itu juga jarang ada TK yang memiliki kegiatan ekstrakurikuler seperti TK Sani Ashila Padang.

TK Sani Ashila setiap setahun sekali mempunyai program Gebyar Sani Ashila dimana siswa akan menampilkan berbagai kesenian pada acara tersebut. Tahun 2017 peneliti pernah mengikuti acara parenting di sekolah tersebut, dan pada acara tersebut anak-anak menyambut pemateri dengan tarian sekapur sirih, drum band, dan paduan suara. Selain itu dibulan April 2018 TK Sani Ashila bekerjasama dengan TV Padang untuk mempromosikan sekolah tersebut, dengan Menampilkan berbagai kesenian berupa tari, puisi, paduan suara, dan juga drum band di acara tersebut. Dalam beberapa kesempatan TK Sani Ashila juga pernah beberapa kali menjuarai perlombaan dari tingkat kecamatan hingga provinsi Sumatra Barat sendiri. Dalam perlombaan tari, TK Sani Ashila pernah menjuarai beberapa perlombaan diantaranya : Trofi berbakat lomba tari minang se Sumatra Barat (25 mai 2014), Trophy berbakat lomba tari minang sekota Padang (19 Februari 2016), Juara 2 lomba tari minang tingkat TK sekota Padang (18 September 2016), Juara 3 tari batok tingkat TK sekota Padang (Sanggar Bungo Tanjung 2016), Juara Favorit tari cewang (KFC 2017), dan juara harapan 2 tari berpasangan/gelatik minang tingkat TK se Kota Padang (2017).

Berdasarkan hal di atas peneliti tertarik untuk mengetahui bagaiman Pelaksanaan Kegiatan ekstrakurikuler tari tradisional di Taman Kanak-Kanak Sani Ashila Padang.

\section{METODE PENELITIAN}

Jenis penelitian ini adalah penelitian deskriptif dengan pendekatan kualitatif. Menurut Moleong (2012:6) penelitian kualitatif adalah penelitian yang bermaksud untuk memahami fenomena tentang apa yang di alami oleh subjek penelitian misalnya perilaku, persepsi, motivasi, dan lain-lain secara holistik, dan dengan cara deskripsi dalam bentuk kata-kata dan bahasa, pada suatu konteks khusus yang alamiah dan dengan memanfaatkan berbagai metode alamiah.

Teknik pengumpulan data yang digunakan adalah observasi, wawancara dan dokumentas. Menurut Sugiyono (2012: 308) teknik pengumpulan data merupakan langkah yang paling strategis dalam 


\section{Jurnal IImiah Potensia, 2019, Vol. 4 (2), 87-94}

https://ejournal.unib.ac.id/index.php/potensia

e-issn: 2621-2382 p-issn: 2527-9270

penelitian, karena tujuan utama dari peneliti adalah mendapatkan data. Arikunto (2010:14) mengemukakan bahwa "observasi adalah mengamati gejala-gejala atau objek yang diteliti secara berulang dengan alat bantu seperti alat pencatatan". Menurut Sugiyono (2011:13) wawancara digunakan sebagai teknik pengumpulan data apabila peneliti ingin melakukan studi pendahuluan untuk menemukan permasalahan yang harus diteliti dan juga apabila peneliti ingin mengetahui hal-hal dari responden yang lebih mendalam dan jumlah respondennya sedikit/kecil. Moleong (2006:201) Dokumentasi adalah bjek yang diperhatikan dalam memperoleh informasi ada tiga yaitu tulisan, tempat, dan kertas atau orang. Mengadakan penelitian yang bersumber dari tulisan inilah maka diperlukan dokumentasi.

Setelah semua data dikumpulkan maka dilakukan teknik keabsahan data. Teknik keabsahan data merupakan data yang diperoleh dari hasil pengumpulan data, maka data tersebut perlu di uji kevalidannya melalui teknik keabsahan data agar data yang diperoleh sah. Dalam penelitian ini teknik keabsahan data yang digunakan adalah trianggulasi teknik. Sugiyono (2010: 274) menjelaskan triangulasi teknik adalah mengetahui kredibilitas data dengan cara mengecek data dari sumber yang sama dengan teknik yang berbeda. Langkah-langkah penelitian yang dilakukan bisa dilihat pada gambar 1 dibawah ini.

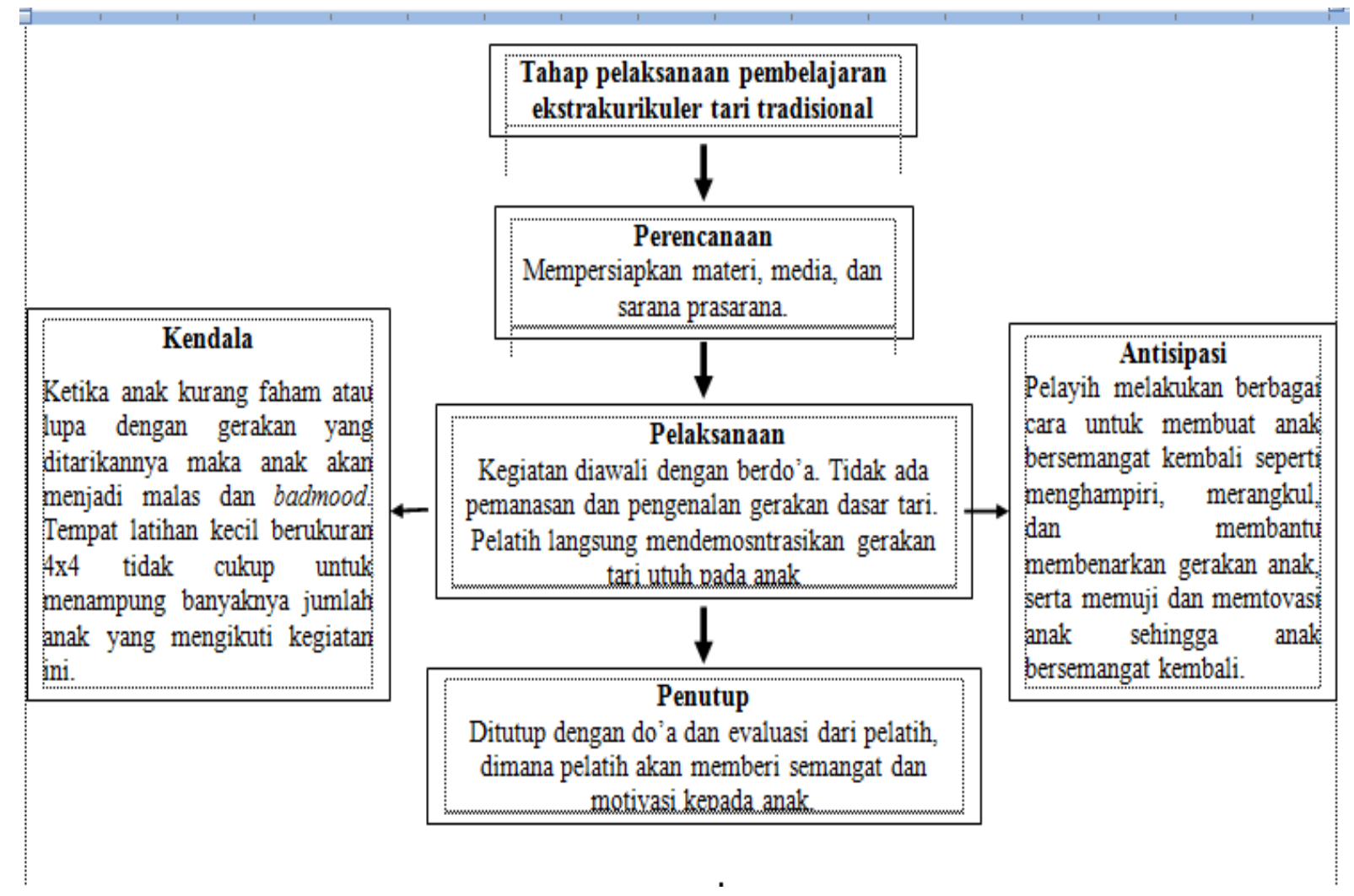

Gambar 1. Kerangka penemuan penelitian pelaksanaan kegiatan ekstrakurikuler tari tradisional di Taman Kanak-Kanak Sani Ashila Padang 


\section{HASIL DAN PEMBAHASAN}

Hasil

Berdasarkan hasil observasi, wawancara, dan dokumentasi yang dilakukan oleh peneliti tahap-tahap dalam pelaksanaan kegiatan ekstrakurikuler tari tradisional ini yaitu pertama adalah perencanaan, yaitu merencanakan materi tari yang akan di ajarkan pada anak, adapun tarian yang diajarkan untuk tahap awal ini adalah Tari Batok. Tujuan Pelaksanaan kegiatan ekstrakurikuler Tari Tradisional ini adalah untuk memperkenalkan kebudayaan daerah kepada anak, salah satunya lewat tari tradisional. Sehingga anak sudah mengenal kebudayaannya sejak dini, Kemudian selain itu juga tujuan pelaksanaan kegiatan ekstrakurikuler ini adalah untuk membantu mengembangkan motorik anak, dan juga rasa percaya diri anak.

Tari ini menggunakan dengan musik pengiring menggunakan fasilitas pemutar musik dari Handphone ataupun Flashdisk yang dihubungkan kepengeras suara. Latihan dilakukan di Aula terbuka TK Sani Ashila sesuai dengan jadwal yang telah ditentukan sebelumnya.

Sebelum kegiatan latihan tari dimulai. Pelatih tari mengumpulkan anak dan merapikan barisan anak-anak agar kegiatan menari kondusif. Kegiatan awal dibuka dengan berdo'a bersama membaca "Bismillah". Guru berperan sebagi demonstrator dimana guru akan memberikan contoh gerakan-gerakan tari batok ini kepada anak, dan anak akan mengikuti gerakan yang dicontohkan oleh pelatih. Anak-anak tidak dipaksa untuk mengikuti kegiatan ini melainkan keinginan mereka sendiri, sehingga dalam pelaksanaannya anak merasa senang dalam mengikuti kegiatan ini. Terakhir dalam penutupan kegiatan selalu ditutup dengan membaca "Alhamdulillah" bersama-sama, kemudian pelatih bertanya bagaimana perasaan anak dan memberikan apresiasi kepada anak. Sebelum pulang anak-anak akan menyalami pelatih satu persatu.

Kendala dalam pelaksanaan kegiatan ekstrakurikuler Tari Tradisional ini adalah dari anak sendiri yaitu kadang anak berada pada masa badmood nya sehingga anak tidak bersemangat dalam mengikuti kegiatan ekstrakurikuler tari Tradisional ini. Selain itu dengan banyaknya anak yang mengikuti kegiatan ini tidak sebanding dengan ukuran aula terbuka yang berukuran $4 \times 4 \mathrm{M}$.

Cara menanggulangi kendala yang dihadapi dalam pelaksanaan kegiatan ekstrakurikuler tari tradisional adalah guru melakukan berbagai cara seperti memberikan motivasi, membujuk dan merangkul anak agar anak kembali bersemangat dalam mengikuti kegiatan ekstrakurikuler tari tradisional. Tempat latihan yang kecil disiasati pelatih dengan membagi anak dalam beberapa kelompok, sehingga kegiatan ekstrakurikuler ini dapat berjalan dengan baik.

\section{Pembahasan}

Berdasarkan data dari hasil penelitian yang telah peneliti lakukan di TK Sani Ashila Pertama, tahap-tahap pelaksanaan kegiatan ekstrakurikuler tari tradisional di TK Sani Ashila yaitu dimulai dari perencanaan yaitu merencanakan materi tari yang akan di ajarkan pada anak, tari yang diajarkan pada anak untuk tahap awal ini adalah tari Batok. Kemudian menyiapkan sarana prasarana seperti tempat akan diadakannya latihan menari. Menyiapkan Media yang dibutuhkan dalam proses kegiatan menari seperti batok, pengeras suara, musik untuk menari. Kemudian pelaksanaan yaitu dimulai dari pembukaan, seperti mengumpulkan anak, berdo'a bersama hingga kegiatan inti yaitu menari. Pelatih berperan sebagai demonstrator dalam kegiatan ini, yaitu guru memperagakan gerakan kemudian anak menirukan gerakan 


\section{Jurnal Ilmiah Potensia, 2019, Vol. 4 (2), 87-94}

https://ejournal.unib.ac.id/index.php/potensia e-issn: 2621-2382 p-issn: 2527-9270

yang diajarkan oleh guru. Terakhir adalah kegiatan penutup yaitu evaluasi oleh pelatih, seperti memberikan apresiasi dan semangat pada anak, serta ditutup dengan berdo'a bersama.

Pelaksanaan kegiatan ekstrakurikuler tari tradisional di TK Sani Ashila dilakukan sebanyak dua kali seminggu, kegiatan yang dilakukan secara rutin inilah yang mampu mengantarkan TK Sani Ashila sebagai juara dalam beberapa lomba tari. Selain tari batok ada banyak jenis tari yang juga diajarkan seperti tari payung, tari pasambahan, dan tari dindin badindin. Tujuan pelaksanaan kegiatan ekstrakurikuler di TK Sani Ashila adalah untuk memperkenalkan akan kayanya kebudayaan indonesia yang berasal dari daerah meraka sendiri lewat tari tradisional yang dikenalkan sejak dini kepada anak. Oleh karena itu semua jenis tari yang diajarkan di TK Sani Ashila adalah tari yang berasal dari daerah sumatera barat sendiri. selain itu juga kegiatan ini dapat membantu mengembangkan motorik lewat gerakangerakan yang ditarikan oleh anak, dan rasa percaya diri anak .

Kendala dalam pelaksanaan kegiatan ekstrakurikuler tari tradisional di TK Sani Ashila adalah anak yang sering berada dalam keadaan bad mood sehingga gurupun harus berusaha membujuk anak agar bersemangat dan mau berlatih kembali. Kondisi Aula teruka berukuran $4 \times 4$ yang digunakan sebagai tempat latihan terlalu sempit jika dibandingkan dengan banyaknya jumlah anak yang mengikuti kegiatan ekstrakurikuler tari tradidional ini.

\section{KESIMPULAN}

Berdasarkan hasil wawancara, observasi, dan dokumentasi pelaksanaan kegiatan ekstrakurikuler tari tradisional di TK sani Ashila Padang dimulai dari proses perencanaan materi, sarana dan prasarana, serta media. Tahap pelaksanaan dimulai dari mengumpulkan anak, berdo'a, dan kegiatan inti yaitu latihan menarikan tari tradisional. Kegiatan akhir yaitu evaluasi oleh pelatih dengan memberikan apresiasi dan semangat kepada anak. Tujuan dilaksanakannya kegiatan ini adalah untuk memperkenalkan kebudayaan indonesia yang berasal dari daerah mereka lewat tari tradisional, kemudian juga untuk membantu perkembangan motorik dan rasa percaya diri anak. Selanjutnya kendala yang ditemui adalah anak yang sering berada dalam keadaan bad mood sehingga guru harus melakukan berbagai cara untuk membujuk anak agar bersemangat kembali untuk berlatih menari. . Selain itu dengan banyaknya anak yang mengikuti kegiatan ini tidak sebanding dengan ukuran aula terbuka yang berukuran $4 \times 4 \mathrm{M}$. Sehingga pelatih harus membagi anak dalam beberapa kelompok untuk menari agar ruangannya mencukupi

Saran

Pelatih sebaiknya menjelaskan tentang tari yang akan di tarikan pada anak, dari mana tari itu berasal, kenapa mereka menarikan tari tersebut, dan apa makna dari tari tersebut, sehingga tujuan untuk memperkenalkan kebudayaan lewat tari kepada anak dapat tercapai. Selanjutnya sebelum memulai latihan menari pelatih hendaknya memandu anak untuk melakukan pemanasan terlebih dahulu, hal ini dapat memperkecil resiko cedera pada saat latihan, kemudian mengajarkan gerakan dasar tari pada anak, terakhir menyesuaikan gerakan tari yang akan diajarkan dengan karakteristik tari anak usia dini, menyesuaikan tari dengan karakteristik anak ini dapat menghindarkan anak dari bad mood. Orangtua yang datang untuk melihat anaknya berlatih seharusnya mempercayakan pelatih untuk melatih anaknya, dan tidak ikut dalam proses kegiatan latihan, karena dapat berefek pada psikologis anak itu sendiri. 


\section{DAFTAR PUSTAKA}

Arikunto, S. (2010). Prosedur Penelitian. Jakarta: Rineka Cipta

Astuti, F. (2016). Pengetahuan dan Teknik Menata Tari Untuk Anak Usia dini. Jakarta : Kencana.

Calista, V., Kurniah, N., \& Ardina, M. (2019). HUBUNGAN REINFORCEMENT TERHADAP DISIPLIN ANAK USIA DINI DI PAUD PEMBINA 1 KOTA BENGKULU (Studi Deskriptif Kuantitatif Di PAUD Pembina 1 Kota Bengkulu). Jurnal Ilmiah POTENSIA, 4(1), 13-17. https://doi.org/10.33369/jip.4.1.13-17

Hadiyanto. (2012). Manajemen Peserta Didik Bernuaansa Pendidikan Karakter. Padang: FIP UNP.

Haryati, T. (2014). Manfaat Belajar Seni Pada Anak Tuna Rungu. Jassi Anakku (Vol. 13, No, 1), 4 .

Husna, M., Pransiska, R., \& Yulsyofriend, Y. (2019). Pengaruh Kegiatan Origami Kertas Washi Terhadap Kreativitas Anak Di Taman Kanak-Kanak Aisyiah No. 1 Muara Panas Kabupaten Solok. Jurnal Ilmiah POTENSIA, 4(1), 67-77. https://doi.org/10.33369/jip.4.1.67-77

Irdawati. (2012). Peningkatan Kemampuan Motorik Kasar Anak Melalui Tari Kreasi di TK Melati Kabupaten Solok Selatan. Pesona PAUD (Volume 1, No.1),10.

IşIk, D., \& TarIm, K. (2009). The effects of the cooperative learning method supported by multiple intelligence theory on Turkish elementary students' mathematics achievement. Asia Pacific Education Review, 10(4), 465-474.

https://doi.org/10.1007/s12564-0099049-5
Juita, R. (2019). Meningkatkan Hasil Belajar IPA Melalui Metode Eksperimen Pada Siswa Kelas IV SDN 02 Kota Mukomuko. IJIS Edu: Indonesian Journal of Integrated Science Education, 1(1), 43-50. Retrieved from

http://ejournal.iainbengkulu.ac.id/inde x.php/ijisedu

Julianti, R., \& Nasirun, H. M. (2018). PELAKSANAAN PERILAKU HIDUP BERSIH DAN SEHAT (PHBS) DI LINGKUNGAN SEKOLAH. Jurnal Ilmiah Potensia (Vol. 3). Retrieved from

https://ejournal.unib.ac.id/index.php/p otensia/article/view/2960/pdf

Kusumah, R. G. T. (2019). Peningkatan Kemampuan Berfikir Kritis Mahasiswa Tadris IPA Melalui Pendekatan Saintifik Pada Mata kuliah IPA Terpadu. IJIS Edu: Indonesian Journal of Integrated Science Education, 1(1), 71-84. Retrieved from

http://ejournal.iainbengkulu.ac.id/inde x.php/ijisedu/article/view/1762

Kusumastuti, E. (2004). Pendidikan Seni Tari Pada Anak Usia Dini Di Taman Kanak-Kanak Tadika Puri Cabang Erlangga Semarang Sebagai Proses Alih Budaya. Jurnal Pengetahuan dan Pemikiran Seni (Vol.V No.1), 12.

Moleong, L. J. (2012). Metode Penelitian Kualitatif: Edisi revisi. Bandung: Remaja Rosda Karya

Novitasari, R., Nasirun, M., \& D., D. (2019). MENINGKATKAN KEMAMPUAN MOTORIK KASAR ANAK MELALUI BERMAIN DENGAN MEDIA HULAHOOP PADA ANAK KELOMPOK B PAUD ALSYAFAQOH KABUPATEN REJANG LEBONG. Jurnal Ilmiah 


\section{Jurnal Ilmiah Potensia, 2019, Vol. 4 (2), 87-94}

https://ejournal.unib.ac.id/index.php/potensia

e-issn: 2621-2382 p-issn: 2527-9270

POTENSIA, 4(1), 6-12. https://doi.org/10.33369/jip.4.1.6-12

Mulyani, N. (2016). Pendidikan Tari Anak Usia Dini. Yogyakarta: Gava Media.

Sapri, J., Agustriana, N., \& Kusumah, R. G. T. (2019). The Application of Dick and Carey Learning Design toward Student's Independence and Learning Outcome. In Proceedings of the International Conference on Educational Sciences and Teacher Profession (ICETeP 2018) (pp. 218222). Paris, France: Atlantis Press. https://doi.org/10.2991/icetep$\underline{18.2019 .53}$

Saripudin, A. (2017). STRATEGI PENGEMBANGAN KECERDASAN NATURALIS PADA ANAK USIA DINI. AWLADY: Jurnal Pendidikan Anak, 3(1).

https://doi.org/10.24235/awlady.v3i1. 1394
Walid, A., Sajidan, S., Ramli, M., \& Kusumah, R. G. T. (2019). Construction of The Assessment Concept to Measure Students' High Order Thinking Skills. Journal for the Education of Gifted Young Scientists, $7(2)$, 237-251. https://doi.org/10.17478/jegys.528180

Wati, K. I., Saparahayuningsih, S., \& Yulidesni, Y. (2017). Meningkatan Keterampilan Motorik Halus Anak Melalui Kegiatan Pembelajaran Membatik Menggunakan Media Tepung Pada Anak Kelompok B PAUD Aisyiyah III Kota Bengkulu. Jurnal Ilmiah POTENSIA, 2(2), 9194. https://doi.org/10.33369/jip.2.2

Sugiyono. (2012). Metode penelitian Pendidikan: Pendekatan Kuantitatif, Kualitatif dan $R$ \& D. Bandung: Alfabeta 